\title{
HAŞIL SÖKME İŞLEMINE ALTERNATİF BİR METOT; OZON UYGULAMASI
}

\author{
İdil YíĞİT* \\ Semiha EREN**
}

Alınma: 26.12.2016; düzeltme: 09.03.2017; kabul: 17.03.2017

\begin{abstract}
Öz: Boya ve bask1 işlemlerinden önce, kumaş üzerindeki haşılın sökülmesi gereklidir. Haşıl sökme, pamuklu kumaşlara uygulanan bir yaş ön terbiye işlemidir. Bu tür yaş ön terbiye işlemlerinin pek çoğu doğaya zarar veren endüstriyel işlemlerdir. Bu sebeple, bu tür yaş işlemlerde çevreye duyarlı, uygun maliyetli yeni stratejilere ihtiyaç duyulmaktadır. Ozonlama işlemi de, tekstil terbiyesinde yeni bir metot olarak yerini almaktadır. Bu çalışmanın amacı; ozon gazı kullanılarak, mevcut haşıl sökme prosesine alternatif bir yöntem göstermektir. Çalışmada, farklı ozonlama sürelerinde (15-30 dakika.) haşıl sökme işlemi gerçekleştirilmiştir. Ozonlanmış numunelere sıcak ve soğuk yıkama ard işlemleri yapılmıştır. Daha sonra ozon gazı ile yapılan haşıl sökmenin değerlendirilebilmesi için, standart haşıl sökme işlemi de (amilaz ile) çalışmaya katılmıştır. Çalışmanın sonunda haşıl sökme derecesi, beyazlık, bitçik sayısı, kopma mukavemeti ve KOİ (Kimyasal Oksijen İhtiyacı) değerleri test edilmiş̧ir. Sonuçlar grafiklerle ve ANOVA istatistiki veri çözümleme metodu ile değerlendirilmiştir. Ozon uygulama süresi arttıkça haşıl sökme oranı da artmış, 30 dakika ozonlama-sıcak yıkama ard işlemi yapılmış uygulamanın haşıl sökme değerlerinin konvansiyonel haşıl sökme yöntemine yakın değerlerde olduğu, bitçik sayısının da anlamlı bir şekilde azaldığı görülmüş̧ür. Ozon uygulama atıklarının, standart haşıl sökme banyo atıklarına göre çok daha düşük KOİ değerlerine sahip olduğu aşikardır. Bu durum da çevresel farkındalık açısından çok önemlidir. Sonuçta, ozonlamanın haşıl sökmeye alternatif bir metot olabileceği ve metodun geliştirilmesi ile haşıl sökme, hidrofilleştirme ve ağartma gibi ön terbiye işlemlerinden tasarruf sağlanacağ düşünülmektedir.
\end{abstract}

Anahtar Kelimeler: Ozonlama, Haşıl sökme, Ekoloji.

\section{Ozone Treatment: An Alternative Approach to Desizing}

\begin{abstract}
It is essential to remove the sizing agents (desizing) prior to coloration for woven textile materials. Although desizing is a common pre-treatment practice, environmental load of the process effluent is usually high. Therefore, new approaches are required in order reduce the environmental impact. Ozone treatment is a novel subject for textile finishing. In this study, ozone gas was utilised for desizing purpose. Various ozone treatment periods $(15-30 \mathrm{~min})$ were applied for desizing. Also conventional enzymatic desizing was applied as the control treatment. Desizing degree, whiteness, mote count, strength and chemical oxygen demand (COD) tests were applied. The results were evaluated by the graphics and the statistical data analysis method ANOVA. Desizing rate increased as the ozone treatment time increased. Also the mote count considerably decreased by the ozone treatment. Moreover, the COD values of the ozone process were less compared to conventional enzymatic treatment. Therefore it was concluded that ozone treatment can be considered as an environmentally friendly alternative in order to other chemical pre-treatment processes like desizing, hydrophilization, bleaching.
\end{abstract}

Key words: Ozone treatment, Desizing, Ecology

*Uludağ Üniversitesi Mühendislik Fakültesi Tekstil Mühendisliği Bölümü, Görükle, Bursa

** Uludağ Üniversitesi Orhangazi Meslek Yüksekokulu Tekstil Teknolojisi Programı, Orhangazi, Bursa

İletişim Yazarı: Semiha EREN (semihaeren@uludag.edu.tr) 


\section{GİRİş}

Tekstil terbiyesinde klasik ön terbiye prosesleri yüksek enerji, su ve kimyasal kullanımı olan haşıl sökme, hidrofilleştirme ve ağartma adımlarını içerir. Genel tekstil terbiyesinde olduğu gibi ön terbiye işlemlerinde de yapılan son çalışmalar daha ekolojik, etkili ve ekonomik prosesler üzerine yoğunlaşmaktadır. Proses içinde kullanılan kimyasallarının daha düşük çevresel etki oluşturan muadilleriyle ikamesi ya da proseste su ve enerji tasarrufu sağlayan gelişmeler tercih edilen yöntemlerdendir. Bu bağlamda yüksek oksidasyon özelliğine sahip olan ozon uygulaması; çevre dostu ve ekonomik yaklaşımları ile tekstilde son zamanlarda üzerinde

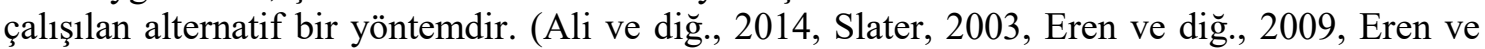
Öztürk, 2011)

Ozon $\left(\mathrm{O}_{3}\right)$ soğuk şartlarda da etkili olan ve atık yük derecesi az olan oksidatif bir gazdır. Ozonun oksidasyon potansiyeli hidrojen peroksitinkinden yüksektir ki bilindiği üzere hidrojen peroksit tekstil terbiyesinde en yaygın kullanılan oksidasyon ajanıdır. Ozon gazı; odun hamuru ağartma prosesleri, gıda ve yiyecek ekipmanlarının hijyeni, gıda işleme ve depolama, havuz hijyeni, içme ve atık sularının temizlenmesi, hayvancılık, tarım, bina dezenfeksiyonu, tedavi ve koruma amaçlı tıbbi uygulamalar gibi pek çok endüstriyel alanda kullanılmaktadır. (Eren ve Öztürk, 2011, Ranjitha ve Balakrishnanb, 2015)

Ozonlama çevre dostu olarak kabul edilebilir çünkü zararlı kimyasallar içermez, suyun kalitesinin düşük olması ozonlamayı etkilemez. (Prabaharan ve diğ.,2000) Ozonlama, bir temiz üretim yöntemidir. Birleşmiş Milletler Çevre Programı (UNEP) tanımına göre; temiz üretim proseslerinin tanımının içinde; "insanlara ve çevreye karşı risklerin azaltılmasını sağlamak amacıyla yapılan üretim" ibaresi bulunmaktadır. (Ul-Haq ve Habib, 2012)

Tekstil endüstrisinde; haşıllama prosesleri gibi yaş prosesler temiz üretim tanımını destekler nitelikte uygulamalar değillerdir. Prosesin deşarj olmuş atık suları, yüksek biyokimyasal ve kimyasal oksijen ihtiyaçları (BOİ-KOİ) ile karakterize edilirler ve tekstil endüstrisindeki asıl kirlilik kaynaklarının başında gelmektelerdir. (Lei ve diğ. 2000, Sun ve diğ.2013)

Haşıllama işlemi ipliğe kayganlık vermenin yanında dokuma yada eğirme işlemleri sırasında ipliğin daha kuvvetli ve stabil olmasını sağlar. Haşıllanmış iplikler daha kolay ayrılabilir ve mekanik etkilere karşı daha dayanıklılardır. Haşıl ajanlarına ek olarak, ipliklerin yumuşak ve düzgün olması için ayrıca elektrostatik etkinin engellenmesi amacıyla banyoya haş1 katkı maddeleri eklenmektedir. Bu katkı maddeleri; yağlar, doğal ve sentetik vakslardır. Tüm bu haşıl ajanları ve katkı maddelerinin boyama ve baskıdan önce uzaklaştırılması gerekmektedir. (Ul-Haq ve Habib, 2012, Lacasse ve Baumann, 2014, Aly ve diğ., 2010, Perinçek ve diğ., 2014, İbrahim ve diğ., 2004)

Nişasta bazlı haşıllama ajanları pamuk ipliklerinin haşıllanmasında yıllardır kullanılan başlıca bileşenlerdir. (Vinay 2007)

Haş1l sökme prosesi, çözgü ipliklerine uygulanmış haş1 komponentlerinin (nişasta, Polivinilalkol (PVA) ve karboksimetilselüloz (CMC) vb) uzaklaştırılması şeklinde yapılmaktadır ve bu işlemin enerji, su ve kimyasal tüketimi çok fazladır. Aynı zamanda tüm tekstil işleminin toplam KOİ'nin \%50-80'ni oluşturmaktadır. (Ali ve diğ., 2014, Lacasse ve Baumann, 2001)

Pamuklu kumaşlara uygulanan geleneksel haşıl sökme işlemi yüksek sıcaklıklarda yıkama ve yüzey aktif maddelerin yüksek konsantrasyonlarda kullanılmasıyla yapılmaktadır. Bunun sonucunda oluşan atık su yüksek KOİ ve BOİ içerir. Bu nedenle; daha az su, enerji ve atık yükü sarfiyatı için, temiz üretime alternatif uygulama metotları aranmaktadır. (Ali, 2014, Feitkenhauer, 2003)

Nişasta haşılının sökülmesinde en yaygın kullanılan yöntemler amilaz enzimi ile haşıl sökme ve oksidatif haş1 sökme yöntemleridir. Literatürde; yüzey aktif maddeler, enzimatik, alkali, oksidatif ve asidik (hidrolitik) yöntemler gibi haşıl maddesini tekstil substratlarından uzaklaştırmak için kullanılan pek çok yöntem özetlenmiştir. (Lacasse ve Baumann, 2004). 
Oksidatif haşıl sökme bilinen bir yöntem olsa da oksidasyon ajanı olarak ozon kullanımı haşıl sökme için yeni bir yöntemdir.

Bu makale; mevcut haşıl sökme proseslerindeki adımları ozon gazı kullanarak iyileştirmeyi amaçlayan ve deneysel verileri içeren bir çalışmayı kapsamaktadır.

\section{MATERYAL VE YÖNTEM}

\subsection{Materyal}

Çalışmada; \%100 pamuk ipliğinden (Ne40/1) oluşan $135 \mathrm{~g} / \mathrm{m}^{2}$ dokuma kumaşlar kullanılmıştır. Nişasta haşılı uygulanmış kumaşlar, Megrel Tekstil A.Ş Bursa, Türkiye'den temin edilmiştir.

Çalışmada klasik haşıl sökme prosesi için amilaz enzimi (Rucolase $\mathrm{HCH}$ ) ve non-iyonik 1slatma ajanı (Rucogen WGA) kullanılmıştır.

Ozonlama işlemleri için gerekli ozon $25 \mathrm{~g} /$ saat kapasiteli Prodozon PRO DO25 model ozon jeneratöründe üretilmiş olup ozonlama işlemleri ise buna bağlı Ataç BB01F numune boyama makinesinin levendine sarılmış kumaş numunesine uygulanmıştır. Ozon jeneratöründen çıkan gaz bir venturi enjektörü ile numune boyama makinesinin çözelti sirkülasyon hattına enjekte edilmiştir. Deneysel düzenek Şekil 1'de verilmiştir. Çalışmalar sırasında gaz akış oranı 5 1/dakika olarak ayarlanmıştır.

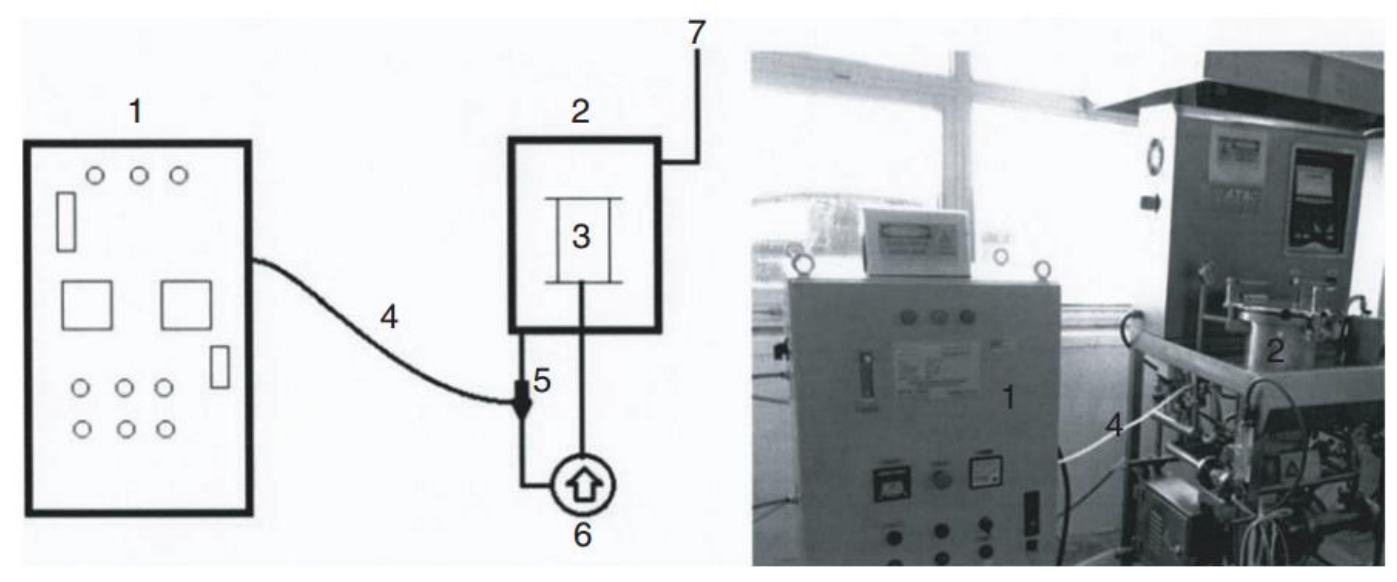

Şekil 1:

Ozon jeneratörü ve entegre numune boyama makinesi ( 1 - ozon jeneratörü; 2 - otoklav; 3 levend; 4 - ozon akış borusu; 5 - venturi enjektörü; 6-sirkülasyon pompası; 7 - ozon çıkışı)

(Eren ve diğ. 2016)

Renk ölçümleri için Konica Minolta CM3600D model spektrofotometre, KOİ ölçümleri için ise Merck KOİ kitleri ile birlikte WTW termoreaktör ve Merck Pharo 300 UV-visible spektrofotometre kullanılmıştır.

\subsection{Yöntem}

Numunelere amilaz ve ozon gazı ile haşıl sökme işlemi uygulanmıştır. Tüm numuneler için deney tekrar sayısı 3 'tür. Sonuçların yorumlanmasında verilerden elde edilen grafikler ve ANOVA istatistiki veri çözümleme metodu kullanılmıştır.

Klasik haş1l sökme yöntemi olarak seçilen amilaz ile haş1l sökme işleminde; numuneler 1 g/lt amilaz (Rucolase $\mathrm{HCH}$ ) ve 1g/l non-iyonik 1slatma ajanı (Rucogen WGA) içeren enzim banyosunda, $90-98^{\circ} \mathrm{C}$ 'de 30 dakika süreyle muamele edilmiştir. Proses sonunda numunelere sıcak yıkama ard işlemi yapılmıştır. 
Ozonla haşıl sökme işleminde ise boyasız-ham pamuklu kumaşlara, farklı sürelerde (15-30 dakika) ozonlama yapılmıştır. Ozonlama sürelerine daha önceki çalışmalar referans alınarak karar verilmiştir. (Vinay, 2007). Makine sıcaklığı 15 dakika ozonlama için $16 \pm 2{ }^{\circ} \mathrm{C}$, 30 dakika ozonlama için ise $20 \pm 2{ }^{\circ} \mathrm{C}$ 'dir. Makinede çözelti pompa yardımıyla sirküle edilmektedir. Ozonlama süresi arttıkça sirkülasyon sebebiyle sıcaklık yükselmesi meydana gelmektedir.

Ozonlama sonrasında sıcak ve soğuk ard yıkama işlemleri yapılmıştır. Ard yıkama işlemlerinin, haşıl sökme derecelerinin artmasına yardımcı olacağı düşünülmüştür. Ard işlemlerin etkisi, sonrasında haşıl sökme dereceleri analiz edilmiştir.

Numunelere; haşıl sökme derecesi, bitçik sayısı (\%), beyazlık dereceleri, kopma mukavemeti, KOİ testleri yapılmış ve deney sonuçları yorumlanmıştır.

\section{Haşıl Sökme}

$\mathrm{I}_{2} / \mathrm{KI}$ çözeltisi ile ölçülmüştür. $\mathrm{I}_{2} / \mathrm{KI}$ çözeltisi numunelerin üzerine damlatılmış, numunelerdeki renk değişimleri ve Tegewa Skalası ile yorumlanmıştır. Tegewa skalası sonuçları 1 ile 9 arasında değerlendirilmektedir. 1 en kötü, 9 ise en iyi haşıl sökme derecesidir.

\section{Beyazlık Tayini}

Ozonlama sonrası numunelerin beyazlık değerleri (Stensby değeri), Konica Minolta CM3600D model spektrofotometre cihazı kullanılarak değerlendirilmiştir. Numunenin her iki yüzü içinde 4 farklı alandan ölçüm yapılmış ve ortalamaları alınmıştır.

\section{Bitçik Sayısı (\%)}

Bitçik sayısı (\%) analizi için numunelerin üzerine işlem öncesi suda çözünmez kalem ile $10 * 10 \mathrm{~cm}^{2}$ 'lik alana işaretleme yapılmış, proses öncesi ve sonrasında işaretli alandaki bitçikler sayılmıştır. İşlem öncesi ve sonrası bitçik oranlarının \% si alınmıştır.

\section{Kopma Mukavemeti}

Kopma mukavemeti testleri ISO 13934-1:2013 'e göre Instron model 4301 test cihazında yapılmıştır.

\section{KOі́}

KOİ değerleri standart titrimetric metoda göre hesaplanmaktadır. (Standard Methods 5220 C: Closed Reflux, Titrimetric Method, APHA, 19th edn, American Public Health Association, 1995).

\section{BULGULAR VE TARTIŞMA}

\subsection{Haşıl Sökme Test Sonuçları}

Numunelerin haşıl sökme dereceleri, numunelerin üstüne $I_{2} / K I$ çözeltisi damlatılarak Tegewa skalası ile renk değişimlerinin derecelendirilmesi şeklinde yapılmış, sonuçlar ise Şekil 2'de verilmiştir.

Yalnızca ozonlama işlemi ile haşı1 sökme dereceleri düşük kaldığından ozon gazı ile haşıl sökme işlemlerinden sonra sıcak ve soğuk yıkama ard işlemleri yapılmıştır.

Şekil 2'de, (3 tekrarlı test sonuçlarının değerlerine göre) konvansiyonel haşıl sökme ve 30 dakika ozonlama-sıcak yıkama ard işlemi yapılmış numunelerin haşıl sökme değerleri Tegewa skalasında 6-7 arasında derecelendirilmiştir. Ancak, 15 dakika ozonlama-soğuk yıkama ard işleminini haşıl sökme değeri 1 derece daha düşük olarak yorumlanmış ve Tegewa skalasında 56 olarak derecelendirilmiştir. Bu sonuçlara göre ozonlama süresi bakımından 30 dakika ozonlamanın uygun olduğu ve sıcak yıkama ard işlemli ozonlama sonuçlarının standart haşıl sökme prosesi kadar iyi olduğu belirlenmiştir.

Diğer yandan, ozonlama-soğuk yıkama ard işlem yapılmış numuneler haşıl sökme açısından sıcak yıkama ard işleminin önemini göstermiştir. Sıcak ard işlemli numunelerde haşıl sökme derecesi daha yüksek bulunmuştur. Soğuk ve sıcak ard işlemli 15 dakika ve 30 dakika 
ozon uygulama sonuçları kıyaslandığında, ozon uygulama süresi arttıkça haşıl sökme oranındaki artış da açıkça görülmüştür. Sonuç olarak, ozonun nişasta moleküllerini oksidasyon efekti ile çözdüğü ve çözünen nişasta partiküllerinin sıcak yıkama ard işlem ile daha kolay uzaklaştırılabildiği sonucuna varılmıştır. Ozonlama işleminde en iyi haşıl sökme değerlerini 30 dakika ozon ve sıcak ard işlem verdiği için istatistiki analiz Amilaz ve 30 dakika ozon uygulaması sonrası sıcak ard işlem olan numuneleri arasında yapılmıştır. Amilaz ile haşıl sökme ve 30 dakika ozon uygulaması sonrası sıcak yıkama ard işlemi yapılan çalışmalar istatistiksel olarak analiz edildiğinde elde edilen analiz sonuçlarına göre \% 5 anlamlılık seviyesinde ( $\mathrm{f}$ hesaplanan $=0,25<\mathrm{f}$ kritik $=7,71)$ iki yöntem arasında haşıl sökme bakımından anlamlı bir fark olmadığı görülmüştür.

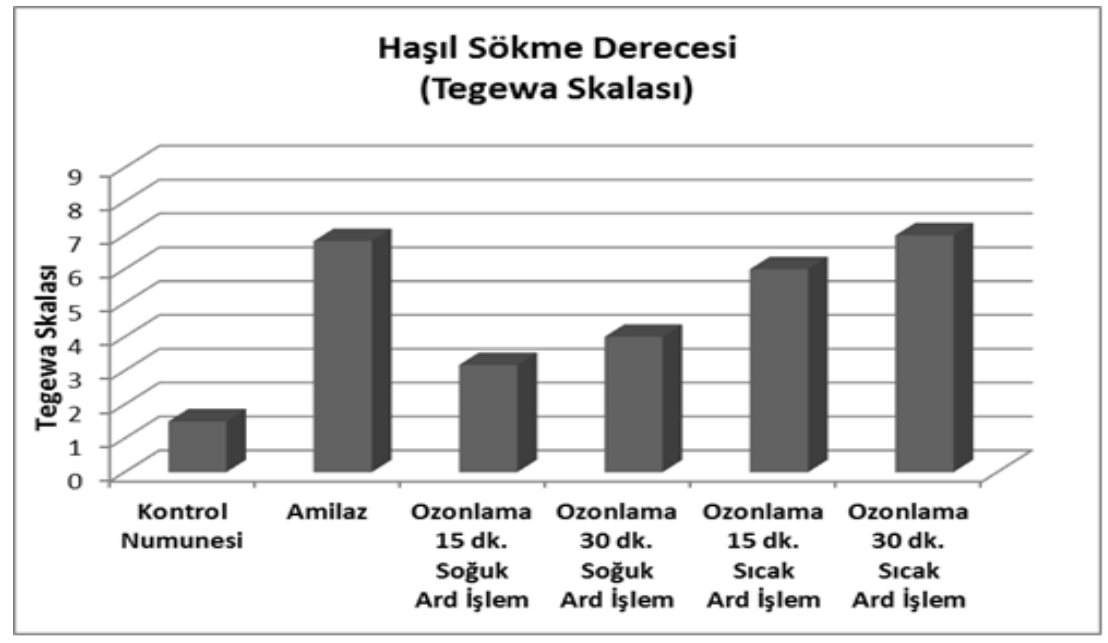

Şekil 2:

Numunelerin Haşıl Sökme Dereceleri

\subsection{Beyazlık Test Sonuçları}

Haş1l sökme uygulamasında hedef beyazlık geliştirmek değildir. Ancak ozonun güçlü oksidatif bir gaz olduğu ve pamuğun beyazlığını arttırdığı bilinmektedir. (Aly ve diğ. 2010, Perinçek ve diğ., 2014). Bu sebeple, Şekil 3'de numunelerin Stensby beyazlık dereceleri sunulmuştur.

Şekil 3, ozonlama süresi arttıkça numunelerin beyazlık derecelerinin de arttı̆̆ını göstermektedir. Standart haşıl sökme prosesinde, haşıl ajanlarının kumaş üzerinden uzaklaştırılmasından dolayı sınırlı bir beyazlık artışı görülmektedir. Fakat ozonlama yapılmış numunelerde, standart prosese kıyasla daha yüksek beyazlık dereceleri elde edilmiştir. Ozon uygulanmış numunelerin beyazlıkları 70 Stensby derecesine (30 dakika ozon ardından sıcak işlem uygulanan numunelerde 72 Stensby) kadar artış göstermiştir.

Konvansiyonel ön terbiye işlemlerinde, beyazlık ağartma ile sağlanır ve pamuk elyafı içinde hidrojen peroksit ağartma ilk seçenek olmaktadır. Bu nedenle, ozon uygulamasının beyazlık derecesi ile kıyaslanabilmesi açısından numunelere hidrojen peroksit ağartma yapılmış ve sonuçları Şekil 3'e eklenmiştir. Sonuçlardan da görülmektedir ki, peroksit ağartma yüksek beyazlık derecesine sahiptir. Ancak haş1 sökme için oluşturulan deneysel plan -ağartma prosesi ile değil- haşıl sökme derecelerine bağlı olarak ozonlama sürelerinin seçimine göre tasarlanmıştır. Böylelikle ozon uygulamasının haşıl sökmenin yanında beyazlık için de yararlı olacağ 1 , elde edilen beyazlığın beyaz kumaşlar için ortalama bir değer olduğuna ve ulaşılan beyazlık değerlerinin koyu renklerde boyanacak kumaşlar için yeterli olduğu kanaatine varılmıştır. Ayrıca sonuçlar; ileriki çalışmalarda ozonlama süreleri uzatılarak tek adımda haşıl sökme ve ağartma proseslerinin gerçekleştirilmesi konusunda cesaret vermektedir.

Kumaşlara haşıl sökme için uygulanan yöntemler beyazlık açısından istatistiki olarak kıyaslandığında (beyazlık sağlamak için kullanılan hidrojen peroksit uygulaması dâhil), \% 5 
anlamlılık seviyesinde istatistiki olarak fark olduğu görülmüştür. ( $f_{\text {hesaplanan }}=221>\mathrm{f}_{\text {kritik }}=3,11$ ) Fakat ozonlama ile gerçekleşen haşıl sökme prosesinden sonra da elde edilen veriler numunelerde ortalama bir beyazlık değeri elde edilebildiğini göstermiştir.

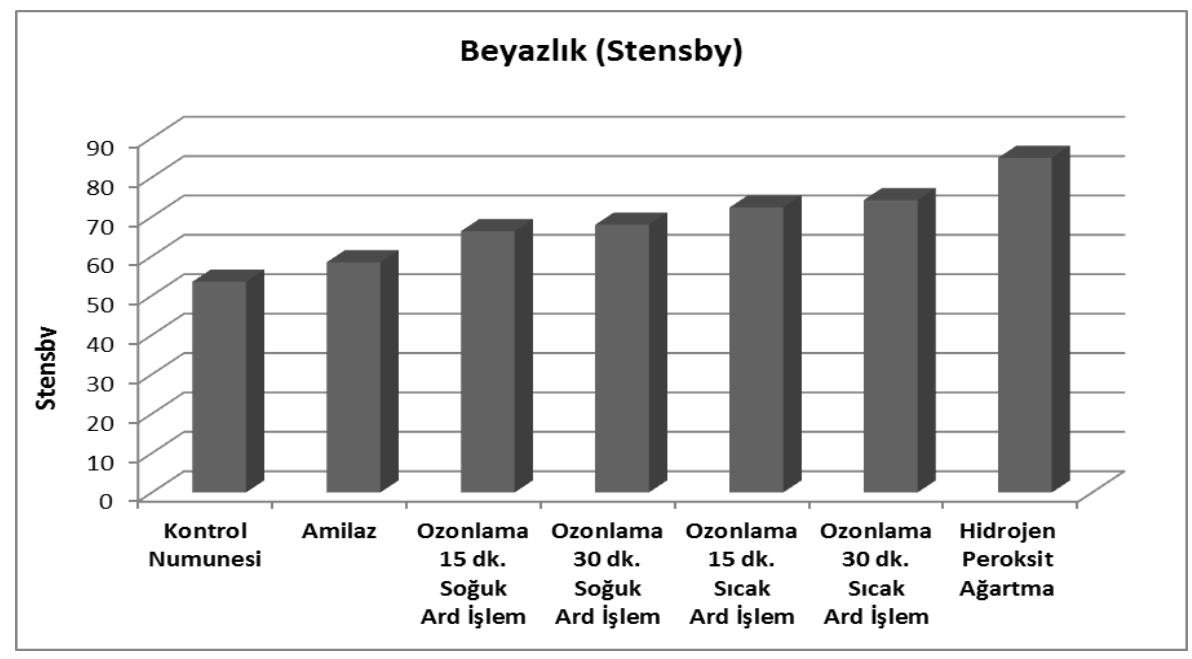

Şekil 3:

Numunelerin beyazlık dereceleri

\subsection{Bitçik Sayısı Test Sonuçları}

Bitçikler, ham kumaşların üstünde görülen, kahverengimsi-siyah renkli, nokta şekilli kirliliklerdir. Pişirme ve ağartma işlemleri kumaştan bitçiğin uzaklaştırılmasından sorumlu konvansiyonel işlemlerdir. Konvansiyonel haşıl prosesi bitçik sökülmesinden sorumlu proses olmasa da, beyazlık sonuçlarına benzer olarak, bitçikler yüksek oksidasyon potasiyeli ve ozonlamanın mevcut sökme etkisinden dolayı kumaştan uzaklaştırılabilmektedirler. Kumaştaki bitçik sayısı Şekil 4'te gösterilmektedir. Yapılan istatistiksel değerlendirmede amilaz ile haş1 sökme işlemi sonrasındaki bitçik değerleri ve 30 dakika ozonlamadan sonraki bitçik değerleri istatistiksel olarak yorumlanmıştır. Analiz sonuçlarına göre ( $\left.\mathrm{f}_{\text {hesaplanan }}=9,2>\mathrm{f}_{\text {kritik }}=5,14\right) \% 5$ anlamlılık seviyesinde istatistiki olarak fark vardır. Fakat konvansiyonel haşıl sökme işleminin bitçik uzaklaştırma gibi bir amacı yoktur ve bitçik sayısının standart haşıl sökme yapılmış numunelerde yüksek değerde olduğu belirtilmelidir. Ancak, 30 dakika ozonlama-sıcak yıkama ard işlemi yapılmış işlemde bitçik sayısının anlamlı bir şekilde azaldığı görülmüştür.

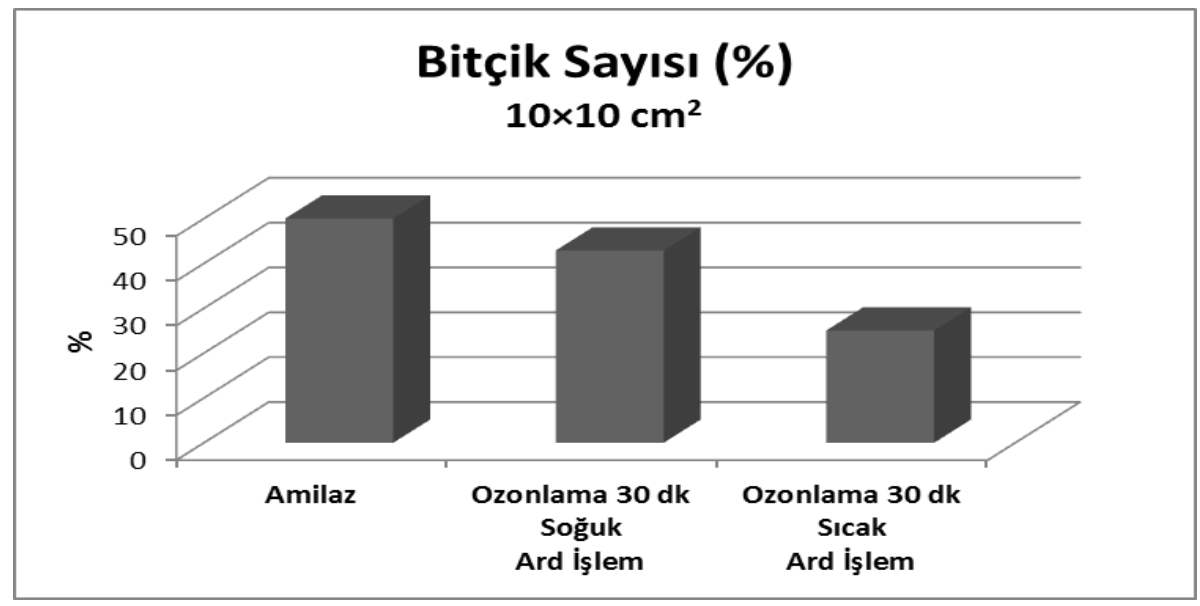

Sekil 4:

Numunelerin bitçik sayısı 


\subsection{Kopma Mukavemeti Test Sonuçları}

Enzim uygulamasına rağmen, amilaz ile haşıl sökme bilinen en güvenilir proseslerden biridir. Oksidatif proseslerde pamuklu kumaşın hasar görmesi konusunda her zaman bir risk vardır. $\mathrm{Bu}$ nedenle, mukavemet testleri, oksidatif uygulamaların değerlendirmelerinde esas alınmaktadır. Numunelerin kopma mukavemetleri Şekil 5 'te verilmiştir. Haşıl sökülmemiş ham kumaşın ortalama mukavemeti $0,77 \mathrm{kN}$, Amilaz ile haşıl sökme işlemi yapılan numunelerin mukavemeti $0,67 \mathrm{kN}, 30$ dakika ozonlanmış, sıcakta ard işlem görmüş numunelerin mukavemeti $0,63 \mathrm{kN}$ 'dur. Şekil 5 'te görüldüğü gibi ozonlanmış numunelerin mukavemet değerlerinde önemsenmeyecek bir düşüş mevcuttur. Bu durumun ozon uygulamasının oksidatif etkisinden kaynaklanması muhtemeldir. Ancak, bu çok az bir düşüştür ve kumaşın mukavemetinde ozonlamanın bir risk oluşturmasında gösterge değildir. Sonuç olarak, kopma mukavemeti test sonuçları göstermektedir ki, amilaz ile haşıl sökme uygulamasına göre 30 dakika ozon uygulaması mukavemette kayda değer bir kayba neden olmamıştır ve kumaş mukavemeti bakımından güvenli olduğu varsayılmaktadır.

Aynı zamanda kumaşa uygulanan her üç haşıl sökme yönteminin kumaş mukavemetine etkisi istatistiksel olarak değerlendirildiğinde; \% 5 anlamlılık seviyesinde istatistiki olarak (f hesaplanan $=4,15<\mathrm{f}$ kritik $=5,14)$ uygulanan işlemler arasında anlamlı bir farklılık olmadığ 1 görülmüştür.

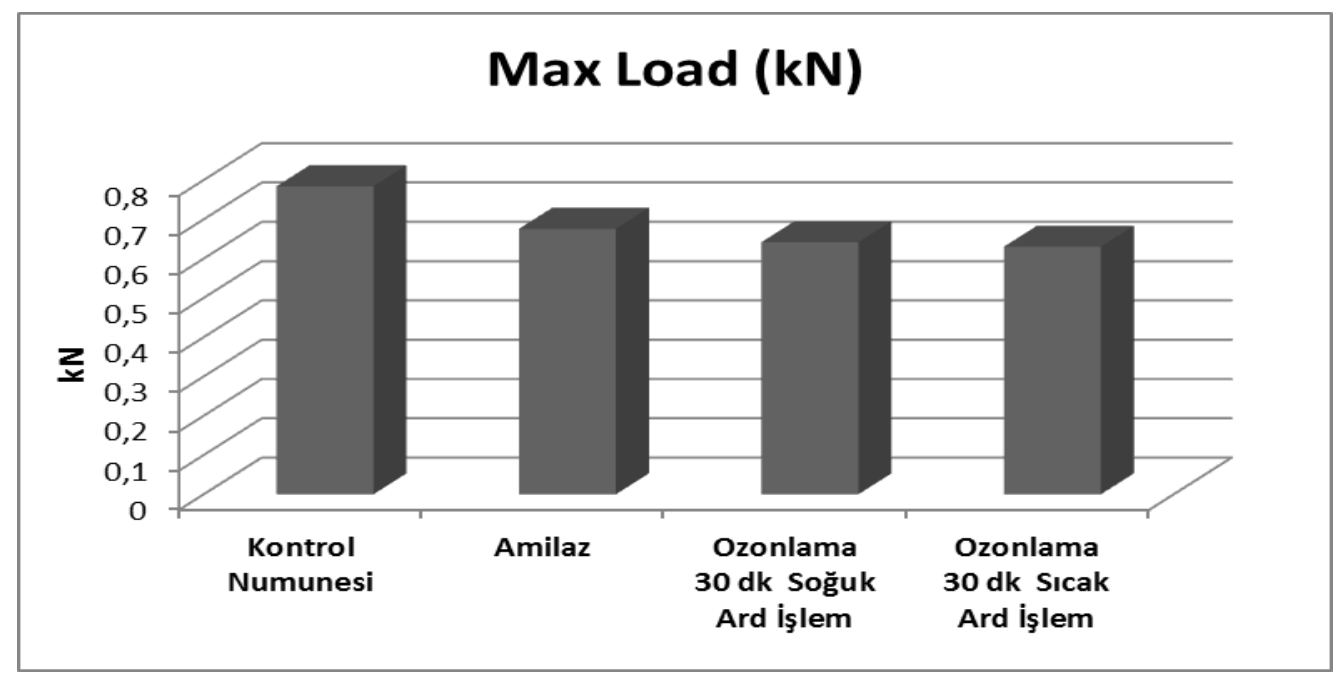

Şekil 5:

Numunelerin mukavemet (Maks. Yük $(k N)$ ) değerleri

\section{5. Çevresel Etki: Kimyasal Oksijen İhtiyacı (KOI) Test Sonuçları}

Günümüzde, çevresel bilinç ve süreçlerin çevresel etkileri önem taşımaktadır. Bu nedenle hem enzim hem de ozon uygulaması banyo atıklarının KOİ değerlendirmeleri gerçekleştirilmiştir. KOİ değerlendirme test sonuçları Şekil 6'da verilmiştir. Yapılan istatistiksel değerlendirmede amilaz ile haşıl sökme sonrasındaki KOİ değerleri ve $30 \mathrm{dk}$ ozonlama banyosundaki KOİ değerleri istatistiksel olarak \% 5 anlamlılık seviyesinde istatistiki olarak fark olduğu görülmüştür. $\left(f_{\text {hesaplanan }}=91,3>f_{\text {kritik }}=7,70\right)$

Ozonlama atıkları, standart haşıl sökme banyo atıklarına göre çok daha düşük KOİ değerlerine sahiptir. Aslında enzim uygulamaları klasik kimyasal kullanan terbiye işlemlerine göre daha 1 lımlı ve çevre dostu olarak kabul edilen proseslerdir. Bu çalışmada uygulanan ozonlama işlemi sonucunda enzimatik haşıl sökme işleminden bile çok daha düşük atık yükü oluşmuştur. Standart haşıl sökme banyosunda birçok kimyasal kullanılmaktadır. Ozonlama ile haş1l sökmede ise ozon gazı dışında hiçbir kimyasal kullanımı yoktur ve ozon zamanla kendi kendine oksijene ayrışabilmektedir. Aynı zamanda ozonun nişasta moleküllerini oksidasyon 
efekti ile çözdüğü de haşıl sökme test sonuçlarında belirtilmiştir. Bu sebeple KOİ ölçüm sonuçları çok düşük çıkmaktadır.

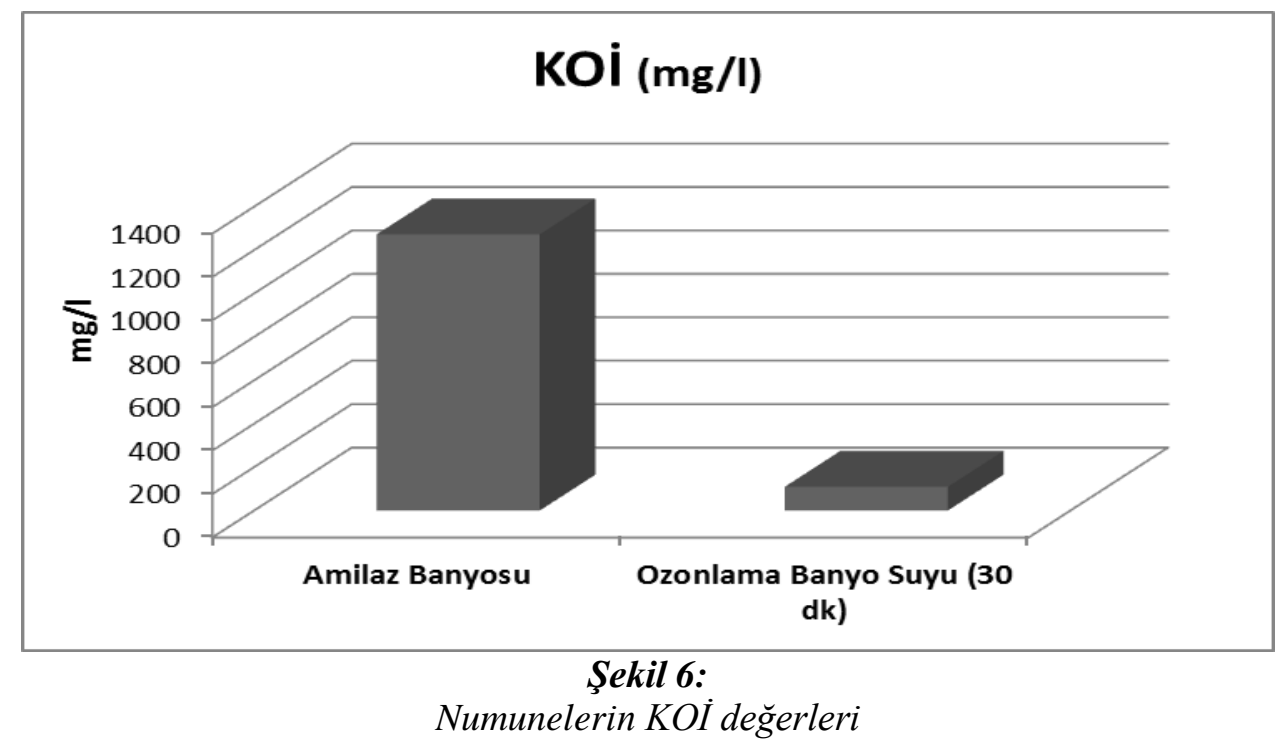

\section{SONUÇ}

Yapılan çalışma göstermektedir ki; ozon uygulama süresi arttıkça haşıl sökme oranı da artmış, 30 dakika ozonlama-sıcak yıkama ard işlemi yapılmış uygulamanın haşıl sökme değerlerinin konvansiyonel haşıl sökme yöntemine yakın değerlerde olduğu, bitçik sayısının da anlamlı bir şekilde azaldığı görülmüştür. Mukavemet test sonuçları ozonlama ile yapılan haşıl sökmedeki mevcut düşük değerin ihmal edilebilir olduğunu, bu düşüşün ozon gazının oksidatifliğinden kaynaklandığ 1 yorumu yapılmıştır. Yapılan haşıl sökme prosesinin amacı kumaşları beyazlatmak olmasa da, elde edilen veriler numunelerde ortalama bir beyazlık değeri elde edilebildiğini göstermiştir. Ozonlama sonucunda çok düşük KOİ değerleri, çevreye duyarlı bir üretim yapılacağı konusunda destekleyici niteliktedir. Alınan veriler ışığında, ozonlamanın haş11 sökmeye alternatif bir metot olabileceği ve bu metodun geliştirilmesi ile haş1 sökme ve ağartma gibi bazı ön terbiye işlemlerinden tasarruf sağlanacağı görüşüne ulaşılmıştır.

\section{KAYNAKLAR}

1. Ali, S., Khatri Z, Khatri A ve Tanwari A. (2014) Integrated desizing-bleaching-reactive dyeing process for cotton towel using glucose oxidase enzyme., Journal of Cleaner Production, 66, 562-567. doi : /10.1016/j.jclepro.2013.11.035

2. Slater, K. (2003) Environmental impact of textiles: production, processes and protection., Woodhead Publishing, Cambridge, İngiltere

3. Eren, A., H., Anis, P., ve Davulcu, A. (2009) Enzymatic one-bath desizing-bleachingdyeing process for cotton fabrics., Textile Research Journal, 79(12), 1091-1098. doi: $10.1177 / 0040517508099388$

4. Eren, H. A., ve Öztürk D. (2011) The evaluation of ozonation as an environmentally friendly alternative for cotton preparation., Textile Research Journal, 81(5), 512-519. doi: 10.1177/0040517510380782

5. Ranjitha D., ve Balakrishnanb P.A. (2015) Study of Bleaching Property of Sago Starch Using Ozonation., National Conference on Research Advances in Communication, 
Computation, Electrical Science and Structures., www.internationaljournalssrg.org. Erişim Tarihi: 15.10 .2016

6. Prabaharan, M., Nayar R.C., Kumar N.S. ve J Venkata Rao J.V. (2000) A study on the advanced oxidation of a cotton fabric by ozone., Coloration Technology, 116(3), 83-86. doi:10.1111/j.1478-4408.2000.tb00024.x

7. Ul-Haq, N., ve Habib N. (2012) Cleaner production technologies in desizing of cotton fabric. Journal of The Textile Institute, 103(3), 304-310. doi:10.1080/00405000.2011.570045

8. Lecheng, L., Chen, G., Porter, J.F., ve Yue, P.L. (2000) Wet air oxidation of desizing wastewater from the textile industry., Industrial \& Engineering Chemistry Research, 3(8), 2896-2901. doi: 10.1021/ie990607s

9. Shiyuan, S., Yu, H., Williams, T. ve Qiu Y. (2013) Eco-friendly sizing technology of cotton yarns with $\mathrm{He} / \mathrm{O} 2$ atmospheric pressure plasma treatment and green sizing recipes., Textile Research Journal, 83(20), 2177-2190.doi: 10.1177/0040517513490061

10. Lacasse, K. ve Baumann, W. (2004) Textile Chemicals: Environmental data and facts., Springer Science \& Business Media, Springer Berlin Heidelberg, Berlin

11. Aly, A. S., Sayed, S.M. ve Zahran, M. K., (2010) One-step process for enzymatic desizing and bioscouring of cotton fabrics., Journal of Natural Fibers, 7(2), 71-92. doi:10.1080/15440478.2010.481086

12. Perinçek, S., Duran, K. ve Körlü, A.E. (2014) Ozonation: a new method which can take place of enzymatic desizing., XIIIth International Izmir Textile and Apparel Symposium, İzmir.

13. İbrahim, N. A., Mamdouh, E.H, Morsy M. S. ve Eid B.M. (2004) Optimization and modification of enzymatic desizing of starch-size., Polymer-Plastics Technology and Engineering, 43(2), 519-538. doi: 10.1081/PPT-120029978

14. Vinay, P., (2007) Environmental aspects of sizing, Chemical Business, Preventation of Air Pollution, (21(7), 41-48.

15. Feitkenhauer, H. ve Meyer. U. (2003) Anaerobic Microbial Cultures in Cotton Desizang: Efficient Combination of Fabric and Wastewater Treatment. Textile Research Journal, 73(2), 93-97. doi: 10.1177/004051750307300201

16. Eren, S., Gümüş, B., Eren, H.A. (2016) Colour Stripping of Reactive-Dyed Cotton by Ozone Treatment, Coloration Technology, 132(6), 466-471. doi: 10.1111/cote.12240 
